\title{
High-frequency Somatic Embryogenesis from Quiescent Seed Cotyledons of Cucumis melo Cultivars
}

\author{
D.J. Gray, D.W. McColley, and Michael E. Compton \\ Central Florida Research and Education Center, Institute of Food and Agricultural Sciences, University \\ of Florida, 5336 University Avenue Leesburg, FL 34748 \\ Additional index words. cantaloupe, melon, muskmelon, cell culture, regeneration
}

\begin{abstract}
A protocol for high-frequency somatic embryogenesis in Cucumis melo L. was developed using 'Male Sterile A147 as a model cultivar. Basal halves of quiescent seed cotyledons were cultured on embryo induction (EI) medium containing concentration ranges of the auxin 2,4-D and the cytokinins BA, Bin, TDZ, or $2 \mathrm{iP}$ before transfer to embryo development (ED) medium. Medium with 2,4-D at $5 \mathrm{mg}^{-1 i t e r}{ }^{-1}$ and TDZ at $0.1 \mathrm{mg} \cdot l i t e r-1$ was superior, with $49 \%$ of explants responding and an average of 3.3 somatic embryos per explant (6.8 somatic embryos per responding explant). More explants produced embryos when incubated on EI medium for 1 or 2 weeks $(30 \%$ and 33\%) than for 3 or 4 weeks or with no induction. However, 2 weeks was 2.9 times better than 1 week in terms of number of embryos per explant. One week of initial culture in darkness, followed by a 16 hour light/8 hour dark photoperiod, produced more responding explants $(26 \%)$ than two or more weeks in darkness or no dark period at all; but 1 and 2 weeks of darkness resulted in a similar number of embryos per explant (2.1 and 2.8). Sucrose concentration in EI and ED media had a highly significant effect on embryo induction and development. EI medium with $3 \%$ sucrose resulted in more embryogenic explants than EI medium with $1.5 \%$ or $6 \%$ sucrose. However, treatments with 3\% sucrose in EI medium and 3\% or 6\% sucrose in ED medium produced significantly more embryos per explant (8.5 and 11.9) than other treatments. Treatments did not affect embryo induction directly and regeneration per se but, instead, frequency and efficiency of somatic embryo development. The optimal treatments were tested with 51 other commercial varieties. All varieties underwent somatic embryogenesis, exhibiting a response of $5 \%$ to $100 \%$ explant response and 0.1-20.2 embryos per explant. Chemical names used: $\mathrm{N}$-(phenylmethyl)-lH-purin-6-amine (benzyladenine or BA); N-(2-furanylmethyl)-lH-purin-6-amine (kinetin or BIN); N-phenyl-N'-1,2,3-thiadiazol-5-ylurea (thidiazuron or TDZ); N-(3-methyl-2-butenyl)-lH-purin-6-amine (2iP); (2,4-dichlorophenoxy) acetic acid (2,4-D).
\end{abstract}

Cucumis melo (cantaloupe, melon, or muskmelon) is subject to several viral diseases that severely limit yield and for which adequate levels of native resistance are not available. A solution to this problem may be to genetically engineer virus resistance into existing germplasm (Nejidat et al., 1990). Adaptation of this technology to commercial varieties and breeding lines of C. melo will require a dependable, high-frequency cell regeneration system. Although organogenic regeneration systems are available (Chee, 1991; Dirks and van Buggenum, 1989; Niedz et al., 1989), our preliminary unpublished experiments demonstrated that regeneration via somatic embryogenesis was more efficient. Somatic embryogenesis was reported for $C$. melo by Homma et al. (1991), Kageyama et al. (1990; 1991), Moreno et al. (1985), Oridate and Oosawa (1986), Shimonishi et al. (1991), Tabei et al. (1991), Trulson and Shahin (1986), and van der Wolk et al. (1986). Diverse explants were used to induce somatic embryogenesis, including quiescent and germinated cotyledons and hypocotyls, leaves, mature seeds, shoot apices, and stems. However, certain important response characteristics, such as embryo quality and number of embryos produced per explant, were low or have not been documented. For example, most published photographs show abnormal (Homma et al., 199 1) or precociously germinating

Received forpublication 10 June 1992. Accepted for publication 30 Oct. 1992. This project was funded in part by USDA/CSRS Special Grant in Tropical/Subtropical Agriculture no. 89-34135-4575 and a grant from the Florida High Technology and Industry Council. Florida Agricultural Experiment Station no. R-02494. We thank Gary W. Elmstrom for providing seeds and for helpful advice during this project. Mention of a trademark, proprietary product, or vendor does not constitute a guarantee or warranty of the product and does not imply its approval to the exclusion of other products or vendors that also may be suitable. The cost of publishing this paper was defrayed in part by the payment of page charges. Under postal regulations, this paper therefore must be hereby marked advertisement solely to indicate this fact.
(Kageyama et al., 1991) somatic embryos. Although plants are often obtained from these embryos, it is not known how such developmental abnormalities may affect actual plant recovery. Similarly, with one exception, where 11 cultivars were tested (Kageyama, 1990), responses of a broad range of genotypes to various published protocols are unknown. Tabei et al. (1991) cultured ungerminated cotyledons of one variety and reported that $83 \%$ of explants produced recognizable somatic embryos, but did not mention the number of embryos obtained per explant. Kageyama et al. (1990) cultured shoot apices from 1- or 2-week-old plants and showed that, for two out of 11 varieties tested, up to $60 \%$ of resulting calluses underwent embryogenesis, producing 2.3 or 3 embryos per callus. One variety produced 10 embryos per explant, but only $10 \%$ of the explants responded. Homma et al. (1991) obtained up to 12.7 embryos per explant, with $85.8 \%$ of explants responding. These are the highest documented responses for $C$. melo.

The purpose of this study was to develop methodology for highfrequency somatic embryogenesis in C. melo with application to many varieties. Effects of various treatments on embryo quality and explant response were categorized, and an optimized protocol was tested on 51 commercially available varieties and one breeding line. The resulting culture system can form the basis for subsequent efforts to engineer virus resistance into this species.

\section{Materials and Methods}

Plant material. Seeds of $C$. melo were surface-disinfested by agitation for $5 \mathrm{~min}$ in $100 \mathrm{ml}$ of an aqueous solution of $1.3 \%$

Abbreviations: ED, embryo development; EI, embryo induction; GM, germination. 
$\mathrm{NaOCl}$ containing a drop of Triton $\mathrm{X}$ surfactant, then rinsed twice and placed for immediate use in sterile distilled water. Embryos were removed from seedcoats, and membranous inner integuments were discarded. Cotyledon explants were carefully dissected from embryos so that most of the cotyledon but none of the hypocotyl was taken. Unless otherwise noted, cotyledons were cut in half crosswise and the distal end was discarded. The remaining proximal parts were cut in half lengthwise and inoculated onto medium. Thus, each seed yielded four explants.

Culture procedure. Four cotyledonary explants were placed in each $90 \times 15 \mathrm{~mm}$ sterile plastic petri dish containing $30 \mathrm{ml}$ of autoclaved EI medium [MS salts (Murashige and Skoog, 1962) with, unless otherwise noted, 1 myo-inositol/liter $\left(\mathrm{g} \cdot \mathrm{liter}^{-1}\right), 1$ nicotinic acid, 10 thiamine $\mathrm{HC} 1,0.5$ pyridoxine $\mathrm{HC} 1$, and $1.5 \%$ sucrose, 0.7\% TC agar (JRH Biosciences, Lenexa Kan.), pH 5.4, with various concentrations of 2,4-D and cytokinins or cytokinic substances, as mentioned below. The dishes were sealed with Parafilm (Fisher Scientific Supply) and incubated in darkness at 25C. Unless otherwise noted, explants were transferred after 2 weeks and incubated in light [16h cool-white fluorescent light (60 $\left.\mu \mathrm{mol} \cdot \mathrm{m}^{-2} \cdot \mathrm{s}^{-1}\right) / 8 \mathrm{~h}$ dark cycle] on ED medium, prepared as above, except with $3 \%$ sucrose and $0.2 \%$ Gelrite instead of agar and lacking growth regulators. To obtain plants, somatic embryos were removed from explants and placed in petri dishes on germination (GM) medium, prepared the same as ED except with MS vitamins, $3 \%$ sucrose, $0.7 \%$ agar, and kept in lighted growth conditions as above. Germinated embryos with roots and shoots were transferred to fresh GM in GA-7 vessels (Magenta Corp., Chicago). Plantlets with three or more expanded leaves were planted in autoclaved commercial potting mix in covered containers and placed in a greenhouse. The transparent covers were removed gradually over 1 week after additional growth was observed; acclimatized plants were potted and grown in a greenhouse to observe morphology and floral development.

Optimization of growth regulators. A series of experiments were conducted to define optimal 2,4-D concentration and cytokinin type and concentration in EI medium.

The first experiment tested 2,4-D at $0,0.1,1$, or $5 \mathrm{mg} \cdot \mathrm{liter}^{-1}$ with BA at $0,0.1$, or $1 \mathrm{mg} \cdot \operatorname{liter}^{-1}$ in a factorial arrangement of treatments. One cotyledon from each seed of 'Male Sterile A147' was cut crosswise and lengthwise to produce four explants, which were placed in a single petri dish. A total of 20 explants, representing tissue from five seeds, were prepared for each treatment.

The experiment to optimize cytokinin type and concentration compared BA, KIN, TDZ (Noram Chemical Co.), and 2iP, each tested at $0.1,1$, or $5 \mathrm{mg} \cdot \operatorname{liter}^{-1}$ in EI medium with 2,4-D at 5 $\mathrm{mg} \cdot \mathrm{liter}^{-1}$. Control treatments with no growth regulator or only 2,4$\mathrm{D}$ were also included. Explants consisted of the proximal half of each seed cotyledon of 'Male Sterile A147', which, was further halved (four explants per seed) and each treatment contained 40 explants (replicates).

Optimal concentration of TDZ was determined by comparing EI media containing $0,0.025,0.05,0.075,0.1,0.125,0.15,0.175$, $0.2,0.4,0.6,0.8$ or $1.0 \mathrm{mg} \cdot$ liter $^{-1}$. Media contained $5 \mathrm{mg} \cdot \mathrm{liter}^{-1} 2,4-$ $\mathrm{D}$ and explants were prepared as in the previous experiment.

Optimization of induction and dark culture periods. Explants (40 to 48 per treatment) of 'Male Sterile A147' were placed on EI medium with 2,4-D at $5 \mathrm{mg} \cdot \operatorname{liter}^{-1}$ and TDZ at $0.1 \mathrm{mg} \cdot \operatorname{liter}^{-1}$. For optimization of induction period, explants were cultured for 0,1 , 2, 3, or 4 weeks on EI medium before transfer to ED medium and were kept in darkness for the entire experiment. For determination of optimal length of the dark period, explants were kept in darkness for $0,1,2,3,4$, or 5 weeks before placement under the light/dark photoperiod noted. In this experiment, all explants, regardless of dark treatment, were kept on EI medium for the first 2 weeks followed by transfer to ED medium. For both experiments, data were taken after 5 weeks on ED medium.

Optimization of sucrose concentration in EI and ED media. EI medium contained 2,4-D at $5 \mathrm{mg} \cdot \mathrm{liter}^{-1}$ and TDZ at $0.075 \mathrm{mg} \cdot \mathrm{liter}^{-1}$. Treatments consisted of various concentrations of sucrose in EI and ED media: Treatment $1=1.5 \%$ sucrose in EI and $1.5 \%$ sucrose in $\mathrm{ED}$; treatment $2=1.5 \%$ and $3 \%$; treatment $3=3 \%$ and $1.5 \%$; treatment $4=3 \%$ and $3 \%$; treatment $5=3 \%$ and $6 \%$; treatment 6 $=6 \%$ and $3 \%$. Each treatment contained 40 explants (replicates) of 'Male Sterile A147', which were cultured for 2 weeks on EI medium and then transferred to ED medium.

Comparison of varieties. The embryogenic response of 55 commercially available varieties to the improved protocol were compared by culturing 60 explants of each on EI medium with 2,4D at $5 \mathrm{mg} \cdot$ liter $^{-1}$, TDZ at $0.75 \mathrm{mg} \cdot \mathrm{liter}^{-1}$ and $3 \%$ sucrose for 2 weeks in darkness before transfer to ED medium in light.

Data acquisition and analysis. Contaminated explants were discarded, resulting in an unequal number of replicates between treatments. For each experiment, the number of explants producing at least 1 embryo was determined after 5 weeks on ED medium. The total number of embryos of three developmental stages were determined as follows: globular stage embryos = distinct globular, clavate structures without signs of cotyledonary development; torpedo stage = elongated, clavate structures, usually with rudimentary cotyledon development; cotyledonary stage = elongated, clavate structure with well developed cotyledons. The total number of embryos per explant was determined by adding together counts for each of these stages. Two additional grading criteria were superimposed on these stages: normal embryo stage $=$ morphologically similar to equivalent zygotic embryo stage; abnormal = exhibited at least one morphological abnormality, i.e., fusion with other embryos, polycotyly, fasciation, grossly misshapen); precocious germination = showing early $\operatorname{sign}(\mathrm{s})$ of germination such as greening, trichome development, elongation, radicle and/ or shoot emergence. Thus, it was possible for an embryo at any developmental stage to be either normal or abnormal and/or precociously germinated.

Data were analyzed with the statistical analysis system using categorical modeling with analysis of standard errors to evaluate number of responding explants and general linear modeling for analysis of embryo number and type per explant (SAS Institute, 1988). Percentage data was subjected to arcsine transformation before analysis to provide a normal distribution.

\section{R esults and Discussion}

Culture initiation and somatic embryo development. Explants enlarged in size and remained white-to-yellowish while on EI medium in darkness. Additional enlargement occurred, up to $500 \%$ of original size, and explants became green when placed on ED medium in light. A limited amount of white-to-yellow callus was produced. Somatic embryos began to appear within 2 weeks after culture initiation. Embryos usually emerged directly from explant tissue and from callus and often occurred in groups or clusters (Fig. 1A). Often, embryos emerging directly from the explant were associated with small amounts of callus and it was unclear whether callus arose from embryogenic cells.

Somatic embryos first appeared as small, hyaline protuberances on the explant surface. These enlarged rapidly into distinct, clavate globular-stage embryos that were attached to the explant by a suspensor-like structure (Fig. 1B). The embryos passed 


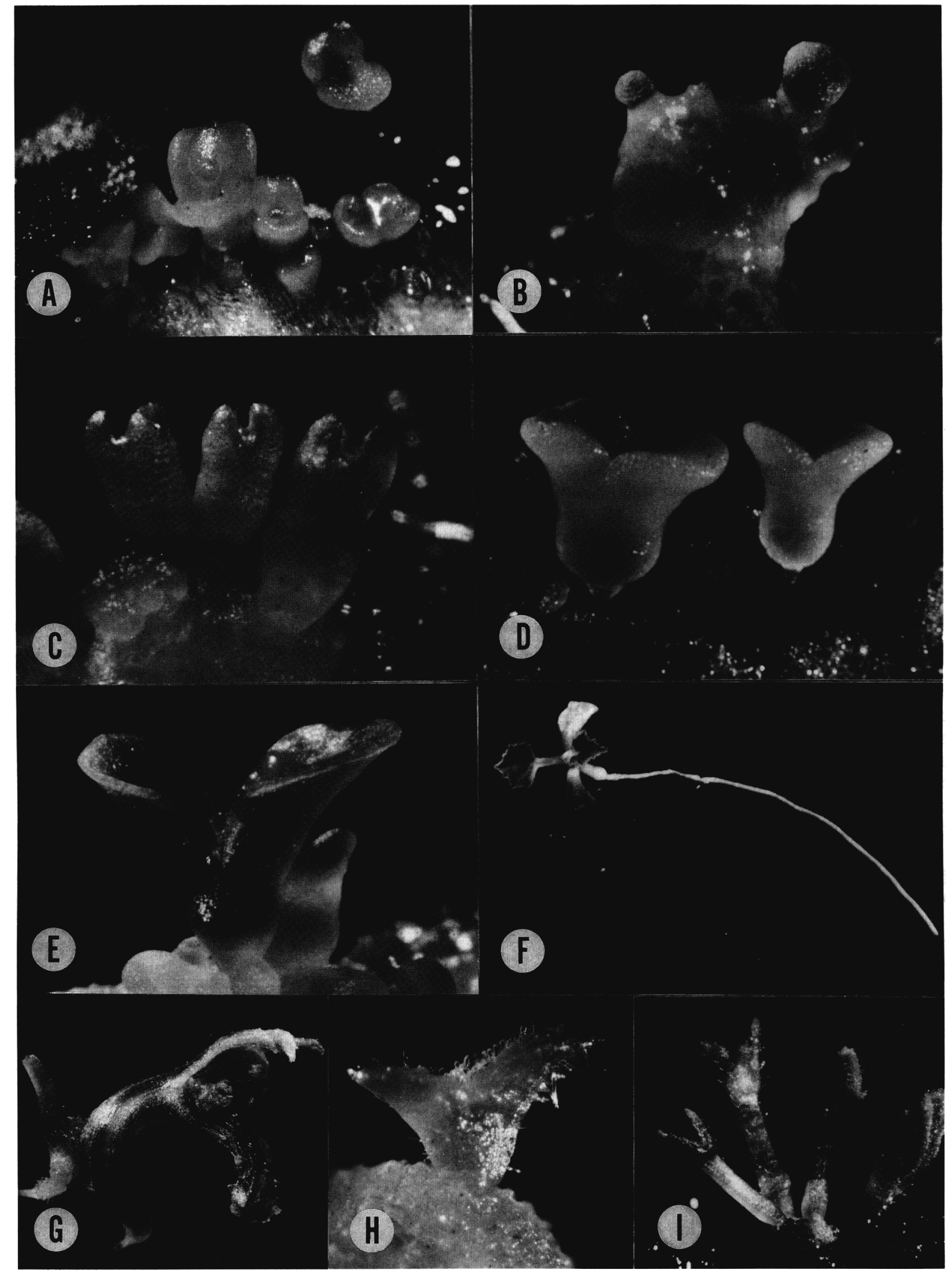

Fig. 1. Somatic embryogenesis from cotyledons of Cucumis melo. (A) Somatic embryos on cotyledon explant $(\times 20)$. (B) Early embryo development from callus. Note hyaline protuberance in middle, with globular stage embryos, attached to callus by suspensors, on either side $(\times 120)$. (C) Late torpedo stage embryos growing from callus. Note early development of cotyledons $(\times 50)$. (D) Cotyledonary stage embryos growing from intact explant. Note fine suspensor attachment of embryos to explant $(\times 35)$. (E) Late cotyledonary stage embryo. Note apical dome visible between expanded cotyledons $(\times 30)$. (F) Plant development from germinated somatic embryo $(\times 2.3)$. (G) Abnormal development of somatic embryos. Two embryos are fused at their hypocotyl regions, with radicles pointing downward. Embryo on left does not have cotyledons, whereas embryo on right displays unusually leafy cotyledons $(\times 10)$. (H) Trichome development on cotyledonary stage embryo signifies precocious germination (×50). (I) Fascicle of precociously germinated embryos. Note early trichome development and hypocotyl elongation $(\times 6)$. 
through recognizable heart-shaped, torpedo (Fig. 1C), and cotyledonary stages (Fig. 1D). Concomitant with morphological development was a change in opacity from hyaline-to-translucent-toopaque and a change in color from pale yellow to yellow to green. Mature somatic embryos possessed two well-defined cotyledons, a cylindrical hypocotyl, and a distinct apical dome situated between the cotyledons (Fig. 1E). Embryos germinated and developed into plants directly on ED medium or when separated from the culture mass and placed directly on GM medium. The axis of germinated embryos elongated to develop into roots and shoots (Fig. 1F). Somatic embryo-derived plants were placed in potting mix and acclimated to greenhouse conditions by an intermediate growth period in a covered moist chamber.

Abnormal somatic embryos were also present. Typical abnormalities included missing, extra, or fused cotyledons, fusion of several embryos at their hypocotyls, or overall grossly misshapen embryo morphology (Fig 1G). Embryos at any developmental stage were capable of precocious germination, which occurred when certain parts of the embryo germinated before full embryo maturation. Precocious germination was recognized by early trichome development on hypocotyls and/or cotyledons (Fig. 1H), hypocotyl elongation (Fig. 11), or cotyledon enlargement and/or premature root emergence. Plants were routinely recovered from abnormal and/or precociously germinated embryos. Presence of a distinct hypocotyl and at least one cotyledon provided a reliable morphological indication that an embryo would likely develop into a complete plant with a root and shoot system if placed on GM. However, we observed that abnormal embryos frequently developed into plants at a slower rate than either normal or precociously germinated embryos. All of $\approx 500$ plants grown to the flowering stage during this study were normal in vegetative and reproductive morphology, regardless of the embryo type from which they arose.

Optimization of growth regulators: Effect of 2,4-D and BA. Comparison of four concentrations of 2,4-D in combination with three concentrations of BA showed that 2,4-D significantly affected the frequency of responding explants, whereas 2,4-D, BA, and their interaction significantly affected the number of embryos

Table 1. Effect of 2,4-D (averaged for all BA levels) and BA (averged for all 2,4-D levels) on somatic embryogenesis from cotyledons of $C$ ucumis melo.

\begin{tabular}{lccc}
\hline $\begin{array}{l}\text { Growth } \\
\text { regulator/ } \\
\text { concn } \\
\left(\mathrm{mg} \cdot \text { liter }^{-1}\right)\end{array}$ & $\begin{array}{c}\text { No. of } \\
\text { explants }\end{array}$ & $\begin{array}{c}\text { Responding } \\
\text { explants } \\
(\%)\end{array}$ & $\begin{array}{c}\text { No. of } \\
\text { embryos/ } \\
\text { explant }\end{array}$ \\
\hline $\begin{array}{l}2,4-\mathrm{D} \\
0\end{array}$ & 60 & $0 \mathrm{c}^{\mathrm{z}}$ & $0 \mathrm{~b}^{\mathrm{y}}$ \\
0.1 & 70 & $7 \mathrm{~b}$ & $0.1 \mathrm{~b}$ \\
1 & 62 & $11 \mathrm{~b}$ & $0.6 \mathrm{~b}$ \\
5 & 67 & $27 \mathrm{a}$ & $2.4 \mathrm{a}$ \\
BA & & $7 \mathrm{~b}$ & $0.1 \mathrm{~b}$ \\
0 & 89 & $16 \mathrm{a}$ & $1.8 \mathrm{a}$ \\
0.1 & 86 & $12 \mathrm{a}$ & $0.5 \mathrm{~b}$ \\
1 & 92 & $*$ & $*$ \\
Main effects & & NS & $*$ \\
$2,4-D$ & & NS & $*$ \\
BA & & & \\
$2,4-D \times$ BA & & & \\
\hline
\end{tabular}

${ }^{\mathrm{z}}$ Mean separation in columns by analysis of standard errors from categorical modeling, $P=0.05$.

y Mean separation in columns by Student-Newman-Keul's test, $P=0.01$.

Ns, ${ }^{*}$ Nonsignificant or significant at $P=0.01$, respectively. per explant (Table 1). When BA concentrations were combined, treatments with 2,4-D at $5 \mathrm{mg} \cdot$ liter $^{-1}$ produced the highest percentage explant response (Table 1). Similarly, BA at 0.1 and $1 \mathrm{mg} \cdot \operatorname{liter}^{-1}$ were better than no BA when 2,4-D levels were combined, demonstrating that BA stimulated embryogenesis. Since the lo-fold difference in BA concentrations between treatments did not result in significantly different responses, it appeared that either BA was not tested at optimal levels or that the presence of BA at either concentration provided adequate effect. Treatments containing 2,4-D at $5 \mathrm{mg} \cdot$ liter $^{-1}$ or BA at $0.1 \mathrm{mg} \cdot$ liter $^{-1}$ were significantly better than others. The interaction between 2,4-D and BA on number of embryos per explant was due to the variable effect of BA at different 2,4-D concentrations. For example, with 2,4-D at 0.1 $\mathrm{mg} \cdot$ liter $^{-1}$, BA at $1 \mathrm{mg} \cdot$ liter $^{-1}$ had the highest percentage of responding explants, whereas, with 2,4-D at 1 and $5 \mathrm{mg} \cdot \mathrm{liter}^{-1}$, BA at 0.1 $\mathrm{mg} \cdot$ liter $^{-1}$ was better (Table 2). Overall best embryogenic response was obtained with 2,4-D at $5 \mathrm{mg} \cdot \operatorname{liter}^{-1}$ and BA at $0.1 \mathrm{mg} \cdot$ liter $^{-1}$. Other reports of somatic embryogenesis in $C$. melo have also used 2,4-D and BA (Oridate and Oosawa, 1986), but 2-naphthaleneacetic acid (NAA) (Homma et al., 1991) and indoleacetic acid (IAA) (Tabei et al., 1991) have also been included. Tabei et al. (1991) showed that 2,4-D concentrations from 1 to $2 \mathrm{mg} \cdot$ liter $^{-1}$ were required to induce embryogenesis, whereas 0 or $0.1 \mathrm{mg} \cdot \mathrm{liter}^{-1}$ concentrations induced shoot organogenesis.

Effect of BA, KIN, TDZ, and $2 i P$. Because BA did not exert a strong influence on somatic embryogenesis, effects of other cytokinins were investigated. Of four cytokinins at three concentrations, TDZ at $0.1 \mathrm{mg} \cdot$ liter $^{-1}$ and $2 \mathrm{iP}$ at $0.1 \mathrm{mg} \cdot$ liter $^{-1}$ produced significantly more embryogenic explants $(70 \%$ and $58 \%$, respectively) than any other treatment (Table 3). However, TDZ at 0.1 $\mathrm{mg} \cdot \mathrm{liter}^{-1}$ produced significantly more embryos per explant when compared to $2 \mathrm{iP}$ at $0.1 \mathrm{mg} \cdot \operatorname{liter}^{-1}(9.5$ vs. 2.8). Benzyladenine, which was used in all previous reports of somatic embryogenesis for this species (Homma et al., 1991; Kageyama et al., 1990; 1991; Oridate and Oosawa, 1986; Punja et al., 1990; Shimonishi et al., 1991; Tabei, 1991; Trulson and Shahin, 1986; van der Wolk et al., 1986), produced a mediocre response when compared to other cytokinins. No significant differences occurred among treatments in number of embryos per responding explant, although a wide range in numerical response was obvious. Here, lack of signifi-

Table 2. Effect of 2,4-D-BA combinations on somatic embryogenesis from cotyledons of Cucumis melo.

\begin{tabular}{lccc}
$\begin{array}{l}2,4-D-B A \\
\left(\mathrm{mg} \cdot \text { liter }^{-1}\right)\end{array}$ & $\begin{array}{c}\text { No. of } \\
\text { explants }\end{array}$ & $\begin{array}{c}\text { Responding } \\
\text { explants } \\
(\%)\end{array}$ & $\begin{array}{c}\text { No. of } \\
\text { embryos/ } \\
\text { explant }\end{array}$ \\
\hline $0-0$ & 20 & $0 \mathrm{~d}^{\mathrm{z}}$ & $0 \mathrm{~b}^{\mathrm{y}}$ \\
$0-0.1$ & 24 & $0 \mathrm{~d}$ & $0 \mathrm{~b}$ \\
$0-1.0$ & 24 & $0 \mathrm{~d}$ & $0 \mathrm{~b}$ \\
$0.1-0$ & 24 & $16 \mathrm{bc}$ & $0.2 \mathrm{~b}$ \\
$0.1-0.1$ & 22 & $0 \mathrm{~d}$ & $0 \mathrm{~b}$ \\
$0.1-1.0$ & 24 & $4 \mathrm{~cd}$ & $0.2 \mathrm{~b}$ \\
$1.0-0$ & 22 & $0 \mathrm{~d}$ & $0 \mathrm{~b}$ \\
$1.0-0.1$ & 16 & $19 \mathrm{~b}$ & $1.5 \mathrm{~b}$ \\
$1.0-1.0$ & 24 & $16 \mathrm{bc}$ & $0.6 \mathrm{~b}$ \\
$5.0-0$ & 23 & $4 \mathrm{~cd}$ & $0.1 \mathrm{~b}$ \\
$5.0-0.1$ & 24 & $46 \mathrm{a}$ & $5.5 \mathrm{a}$ \\
$5.0-1.0$ & 20 & $30 \mathrm{ab}$ & $1.2 \mathrm{~b}$ \\
\hline
\end{tabular}

${ }^{2}$ Mean separation in columns by analysis of standard errors from categorical modeling, $P=0.05$.

y Mean separation in columns by Student-Newman-Keul's test, $P=0.01$. 
Table 3. Effect of cytokinin type and concentration on somatic embryogenesis from cotyledons of Cucumis melo.

\begin{tabular}{|c|c|c|c|c|}
\hline $\begin{array}{l}\text { Cytokinin } \\
\text { and concn } \\
\left(\mathrm{mg} \cdot \text { liter }^{-1}\right)\end{array}$ & $\begin{array}{l}\text { No. of explants } \\
\text { tested }\end{array}$ & $\begin{array}{c}\text { Responding } \\
\text { explants } \\
(\%)\end{array}$ & $\begin{array}{l}\text { No. of embryos/ } \\
\text { explant }\end{array}$ & $\begin{array}{l}\text { No. of embr- } \\
\text { yos/responding } \\
\text { explant }\end{array}$ \\
\hline 0 (control) & 40 & $3 \mathrm{e}^{\mathrm{z}}$ & $0.1 \mathrm{c}^{\mathrm{y}}$ & $4.0 \mathrm{a}^{\mathrm{y}}$ \\
\hline \multicolumn{5}{|l|}{ TDZ } \\
\hline 0.1 & 52 & $70 a$ & $9.5 \mathrm{a}$ & $13.7 \mathrm{a}$ \\
\hline 1.0 & 51 & $12 \mathrm{~cd}$ & $0.3 \mathrm{c}$ & $2.7 \mathrm{a}$ \\
\hline 5.0 & 52 & $0 \mathrm{f}$ & $0.0 \mathrm{c}$ & NA \\
\hline \multicolumn{5}{|l|}{ BA } \\
\hline 0.1 & 48 & $35 \mathrm{~b}$ & $1.5 \mathrm{bc}$ & $8.0 \mathrm{a}$ \\
\hline 1.0 & 48 & $13 \mathrm{~cd}$ & $1.0 \mathrm{bc}$ & $1.3 \mathrm{a}$ \\
\hline 5.0 & 64 & $3 \mathrm{e}$ & $0.3 \mathrm{c}$ & $8.0 \mathrm{a}$ \\
\hline \multicolumn{5}{|l|}{$2 \mathrm{iP}$} \\
\hline 0.1 & 48 & $58 \mathrm{a}$ & $2.8 \mathrm{~b}$ & $4.8 \mathrm{a}$ \\
\hline 1.0 & 59 & $40 \mathrm{~b}$ & $1.8 \mathrm{bc}$ & $4.7 \mathrm{a}$ \\
\hline 5.0 & 44 & $18 \mathrm{c}$ & $0.5 \mathrm{bc}$ & $2.6 \mathrm{a}$ \\
\hline \multicolumn{5}{|l|}{ KIN } \\
\hline 0.1 & 60 & $20 \mathrm{c}$ & $0.7 \mathrm{bc}$ & $3.3 \mathrm{a}$ \\
\hline 1.0 & 62 & $33 \mathrm{~b}$ & $2.3 \mathrm{bc}$ & $6.9 \mathrm{a}$ \\
\hline 5.0 & 60 & $5 \mathrm{de}$ & $0.1 \mathrm{c}$ & $1.3 \mathrm{a}$ \\
\hline
\end{tabular}

${ }^{\mathrm{z}}$ Mean separation in columns by analysis of standard errors from categorical modeling, $P=0.05$. y'Mean separation in columns by Student-Newman-Keul's test, $P=0.01$.

$\mathrm{NA}=$ not applicable.

Table 4. Effect of thidiazuron concentration on somatic embryogenesis from cotyledons of Cucumis melo.

\begin{tabular}{|c|c|c|c|c|c|c|}
\hline \multirow[b]{2}{*}{$\begin{array}{l}\text { Thidiazuron } \\
\left(\mathrm{mg} \cdot \text { liter }^{-1}\right)\end{array}$} & \multirow[b]{2}{*}{$\begin{array}{l}\text { No. of explants/ } \\
\text { percent response }\end{array}$} & \multirow[b]{2}{*}{$\begin{array}{l}\text { No. of } \\
\text { embryos }^{2}\end{array}$} & \multicolumn{4}{|c|}{ Embryo type/total embryos (\%) } \\
\hline & & & Globular & Torpedo & Cotyledonary & $\begin{array}{l}\text { Precocious } \\
\text { germination }\end{array}$ \\
\hline 0.0 & $40 / 5 \mathrm{ef}^{y}$ & $0.1 \mathrm{c} / 4.0 \mathrm{a}^{\mathrm{x}}$ & $100 \mathrm{a}$ & $0 \mathrm{a}$ & $0 \mathrm{a}$ & $0 \mathrm{c}$ \\
\hline 0.025 & $35 / 31 \mathrm{~b}$ & $2.2 \mathrm{~b} / 6.9 \mathrm{a}$ & $42 \mathrm{a}$ & $21 \mathrm{a}$ & $37 \mathrm{a}$ & $29 a b$ \\
\hline 0.05 & $40 / 15$ cde & $0.3 \mathrm{c} / 3.0 \mathrm{a}$ & $17 \mathrm{a}$ & $33 \mathrm{a}$ & $50 \mathrm{a}$ & $15 \mathrm{bc}$ \\
\hline 0.075 & $35 / 49$ a & $3.3 \mathrm{a} / 6.8 \mathrm{a}$ & $31 \mathrm{a}$ & $36 \mathrm{a}$ & $33 \mathrm{a}$ & 37 a \\
\hline 0.1 & $38 / 13$ cde & $0.5 \mathrm{c} / 3.8 \mathrm{a}$ & $20 \mathrm{a}$ & $25 \mathrm{a}$ & $55 \mathrm{a}$ & $13 \mathrm{bc}$ \\
\hline 0.125 & $40 / 18 \mathrm{bcd}$ & $0.6 \mathrm{c} / 3.6 \mathrm{a}$ & $32 \mathrm{a}$ & $25 \mathrm{a}$ & $43 \mathrm{a}$ & $15 \mathrm{bc}$ \\
\hline 0.15 & $34 / 6$ ef & $0.3 \mathrm{c} / 5.5 \mathrm{a}$ & $50 \mathrm{a}$ & $7 \mathrm{a}$ & $43 \mathrm{a}$ & $6 \mathrm{c}$ \\
\hline 0.175 & $40 / 20 \mathrm{bc}$ & $0.5 \mathrm{c} / 2.5 \mathrm{a}$ & $75 \mathrm{a}$ & $13 \mathrm{a}$ & $12 \mathrm{a}$ & $13 \mathrm{bc}$ \\
\hline 0.2 & $36 / 19 \mathrm{bcd}$ & $0.6 \mathrm{c} / 3.3 \mathrm{a}$ & $3 \mathrm{a}$ & $69 a$ & $28 \mathrm{a}$ & $19 \mathrm{bc}$ \\
\hline 0.4 & $40 / 0 \mathrm{f}$ & $0.0 \mathrm{c} / \mathrm{NA}$ & $0 \mathrm{a}$ & $0 \mathrm{a}$ & $0 \mathrm{a}$ & $0 \mathrm{c}$ \\
\hline 0.6 & $40 / 0 \mathrm{f}$ & $0.0 \mathrm{c} / \mathrm{NA}$ & $0 \mathrm{a}$ & $0 \mathrm{a}$ & $0 \mathrm{a}$ & $0 \mathrm{c}$ \\
\hline 0.8 & $36 / 3 \mathrm{f}$ & $0.3 \mathrm{c} / 1.0 \mathrm{a}$ & $0 \mathrm{a}$ & $100 \mathrm{a}$ & $0 \mathrm{a}$ & $100 \mathrm{c}$ \\
\hline 1.0 & $36 / 8 \mathrm{def}$ & $0.3 \mathrm{c} / 3.0 \mathrm{a}$ & $100 \mathrm{a}$ & $0 \mathrm{a}$ & $0 \mathrm{a}$ & $0 \mathrm{c}$ \\
\hline
\end{tabular}

${ }^{\mathrm{z}}$ Embryos per total number of explants/embryos per responding explants.

y Mean separation in columns by analysis of standard errors from categorical modeling, $P=0.05$.

'Mean separation in columns by Student-Newman-Keul's test, $P=0.01$.

$\mathrm{NA}=$ not applicable.

cance was due to the high degree of variability in response among responding explants. Those results suggested that differences among cytokinin treatments were primarily due to their ability to induce explants to respond (i.e., produce at least one embryo). However, when considering only responding explants, cytokinins did not affect the actual number of embryos produced.

Since TDZ at $0.1 \mathrm{mg} \cdot$ liter $^{-1}$ produced the most embryos in the previous experiment, a more finely defined range of TDZ concentrations, above and below $0.1 \mathrm{mg} \cdot$ liter $^{-1}$, was subsequently studied (Table 4). We found that TDZ at $0.075 \mathrm{mg} \cdot$ liter $^{-1}$ produced significantly more embryogenic responding explants (49\%) and more embryos per explant (3.3) when compared to other concentrations tested. The second best treatment was TDZ at $0.025 \mathrm{mg} \cdot \mathrm{liter}^{-1}$
(31\% explant response and 2.2 embryos per explant); all other treatments produced fewer than $20 \%$ embryogenic explants and 0.6 embryos per explant. The lower response of TDZ at 0.05 $\mathrm{mg} \cdot \mathrm{liter}^{-1}$ is unclear within the context of this experiment, but could be due to variability inherent in this system. As discussed previously, there were no differences among treatments in number of embryos per responding explant.

There were no significant differences among TDZ treatments in the percentage of embryo stages produced, although recovery of a particular stage could range from $0 \%$ to $100 \%$ among treatments (Table 4). This is again due to wide variation in response between replicates and suggests that TDZ concentration does not affect the rate of embryo development. A significant difference was noted 
Table 5. Effects of time on induction medium and initial dark period on somatic embryogensis from cotyledons of Cucumis melo.

\begin{tabular}{lccccc}
\hline \hline & \multicolumn{2}{c}{ Time on induction medium } & & \multicolumn{2}{c}{ Length of dark period } \\
\cline { 2 - 3 } \cline { 5 - 6 } & $\begin{array}{c}\text { No. of explants/ } \\
\text { percent response }\end{array}$ & No. of embyos ${ }^{\mathrm{y}}$ & & $\begin{array}{c}\text { No. of explants/ } \\
\text { percent response }\end{array}$ & No. of embryos ${ }^{\mathrm{z}}$ \\
\hline 0 & $36 / 0 \mathrm{~d}^{\mathrm{x}}$ & $0.0 \mathrm{~b} / \mathrm{NA}^{\mathrm{w}}$ & & $80 / 10 \mathrm{~b}^{\mathrm{x}}$ & $0.5 \mathrm{~b} / 5.0 \mathrm{a}^{\mathrm{w}}$ \\
1 & $56 / 30 \mathrm{a}$ & $1.2 \mathrm{~b} / 4.0 \mathrm{ab}$ & & $68 / 26 \mathrm{a}$ & $2.8 \mathrm{a} / 11.0 \mathrm{a}$ \\
2 & $40 / 33 \mathrm{a}$ & $3.5 \mathrm{a} / 11.0 \mathrm{a}$ & & $76 / 14 \mathrm{~b}$ & $2.1 \mathrm{a} / 15.0 \mathrm{a}$ \\
3 & $52 / 15 \mathrm{~b}$ & $0.4 \mathrm{~b} / 3.0 \mathrm{~b}$ & & $76 / 3 \mathrm{~b}$ & $0.1 \mathrm{~b} / 2.0 \mathrm{a}$ \\
4 & $36 / 8 \mathrm{~b}$ & $0.4 \mathrm{~b} / 5.0 \mathrm{ab}$ & & $80 / 1 \mathrm{~b}$ & $0.1 \mathrm{~b} / 4.0 \mathrm{a}$ \\
5 & & & & $80 / 4 \mathrm{~b}$ & $0.1 \mathrm{~b} / 3.0 \mathrm{a}$ \\
Duration & & & & $5 / 2 \mathrm{~b}$ & $0.1 \mathrm{~b} / 1.0 \mathrm{a}$ \\
\hline
\end{tabular}

${ }_{\mathrm{z}}^{\mathrm{Refers}}$ to period on induction medium and to initial period in darkness.

${ }^{y}$ Embryos per total number of explants/embryos per responding explants.

x Mean separation in columns by analysis of standard errors from categorical modeling, $P=0.05$.

wean separation in columns by Student-Newman-Keul's test, $P=0.01$.

for precocious germination. Here, the TDZ concentration that produced the highest embryogenic response $\left(0.075 \mathrm{mg} \cdot \mathrm{liter}^{-1}\right)$ also resulted in the most precocious germination. This result suggests that treatments maximizing embryo development also encourage precocious germination. It is also possible that embryos were initiated earlier and/or developed faster with this treatment and, therefore, more had germinated when the experiment was graded. Consideration of these results in light of previously published photographs of precociously germinating somatic embryos (Homma et al., 1991; Kageyama et al., 1991; Oridate and Oosawa, 1986; Tabei, et al., 1991) suggests that precocious germination is a common feature of $C$. melo somatic embryos. Embryo maturation that culminates in a quiescent phase, as happens with C. melo seed embryos, does not occur with somatic embryos. Lack of adequate maturation and onset of quiescence are common features of somatic embryos produced in vitro (Gray and Purohit, 1991). Perhaps further refinements to the culture system would promote more normal development. Although TDZ has been used effectively for plant regeneration from tissue cultures of several crops (Malik and Saxena, 1992; Nugent et al., 1991), its usefulness for inducing somatic embryogenesis in cucurbits has not been adequately documented beyond our previous presentations concerning Citrullus lanatus (Thunb.) Matsum. \& Nakai (Compton and Gray, 1991; 1993) and C. melo (Gray et al., 1992). Of the four cytokinins tested to date, TDZ is clearly superior. Thidiazuron cannot be regarded as a superior cytokinin in all instances, however, since we have shown that it is not better than BA for adventitious shoot development in watermelon (Compton and Gray, 1993) or muscadine grape (Vitis rotundifolia Michx.) (Gray and Benton, 1991).
Effect of induction period. A higher percentage of explants produced somatic embryos when kept on EI medium for 1 or 2 weeks when compared to longer times or no induction period (Table 5). However, significantly more embryos were produced only after a 2-week induction. Induction periods of 1, 2, or 4 weeks were statistically similar when considering the number of embryos per explant.

Effect of dark period. More explants responded after incubation for 1 week in darkness, followed by transfer to a light/dark photoperiod, when compared to 2 to 5 weeks in darkness or no dark period at all (Table 5). Both 1 and 2 weeks of darkness were better than other treatments when considering the total number of embryos obtained, but there were no differences for number of embryos per explant. The requirement of explants for a dark incubation period, as compared to a light/dark photoperiod, suggests that induction of somatic embryogenesis may be adversely affected by the development of chloroplasts, since explants kept in darkness remain unpigmented, whereas those in light become green.

Effect of sucrose concentration. The concentration of sucrose in EI and ED media had a profound effect on somatic embryogenesis (Table 6). Three percent in EI medium produced a greater explant response than lower or higher concentrations. For those treatments with only $3 \%$ sucrose in EI medium, there was no statistical difference among sucrose concentrations $(1.5 \%, 3.0 \%$, or $6.0 \%)$ in ED medium. However, when considering total number of embryos produced, the two treatments with $3.0 \%$ or $6.0 \%$ sucrose in ED medium were better than the treatment with $1.5 \%$. Similarly, treatments with at least 3\% sucrose in EI medium and 3\% sucrose

Table 6. Effect of sucrose concentration in embryo induction (EI) and embryo development media on somatic embryo count and quality from cotyledons of Cucumis melo.

\begin{tabular}{|c|c|c|c|c|c|c|}
\hline \multirow{2}{*}{$\begin{array}{l}\text { Sucrose } \\
\left(\mathrm{g} \cdot \text { liter }^{-1}\right) \\
\text { in EI-ED }\end{array}$} & \multirow[b]{2}{*}{$\begin{array}{l}\text { No. of explants/ } \\
\text { percent response }\end{array}$} & \multirow[b]{2}{*}{$\begin{array}{l}\text { No. of } \\
\text { embryos }^{2}\end{array}$} & \multicolumn{4}{|c|}{ Embryo type/explant (\%) } \\
\hline & & & Torpedo & Cotyledonary & Abnormal & $\begin{array}{l}\text { Precocious } \\
\text { germination }\end{array}$ \\
\hline $1.5-1.5$ & $36 / 33 b^{y}$ & $2.2 \mathrm{~b} / 6.6 \mathrm{~b}^{\mathrm{x}}$ & $0.2 \mathrm{~b}$ & $29 \mathrm{~b}$ & $33 \mathrm{~b}$ & $28 \mathrm{~b}$ \\
\hline $1.5-3.0$ & $35 / 17 \mathrm{c}$ & $0.9 \mathrm{~b} / 5.3 \mathrm{~b}$ & $0.0 \mathrm{~b}$ & $18 \mathrm{~b}$ & $25 \mathrm{~b}$ & $25 \mathrm{~b}$ \\
\hline $3.0-1.5$ & $32 / 77$ a & $4.0 \mathrm{~b} / 5.8 \mathrm{~b}$ & $19.0 \mathrm{a}$ & $54 \mathrm{ab}$ & $69 a b$ & $69 a$ \\
\hline $3.0-3.0$ & $35 / 68 \mathrm{a}$ & $11.9 \mathrm{a} / 15.3 \mathrm{a}$ & $15.0 \mathrm{ab}$ & $54 \mathrm{ab}$ & $100 \mathrm{a}$ & $99 \mathrm{a}$ \\
\hline $3.0-6.0$ & $32 / 81$ a & $8.5 \mathrm{a} / 10.4 \mathrm{ab}$ & $5.0 \mathrm{ab}$ & $73 \mathrm{a}$ & $91 \mathrm{a}$ & 91 a \\
\hline $6.0-3.0$ & $36 / 22 \mathrm{bc}$ & $3.8 \mathrm{~b} / 17.1 \mathrm{a}$ & $0.0 \mathrm{~b}$ & $22 \mathrm{~b}$ & $33 \mathrm{~b}$ & $33 \mathrm{~b}$ \\
\hline
\end{tabular}

mer total number of explants/embryos per responding explants.

${ }^{\mathrm{y}}$ Mean separation in columns by analysis of standard errors from categorical modeling, $P=0.05$.

'Mean separation in columns by Student-Newman-Keul's test, $P=0.01$. 
Table 7. Response of cotyledon explants from Cucumis melo varieties to improved culture protocol.

\begin{tabular}{|c|c|c|c|}
\hline Variety & $\begin{array}{l}\text { No. of } \\
\text { explants }\end{array}$ & $\begin{array}{l}\text { Responding } \\
\text { explants } \\
(\%)\end{array}$ & $\begin{array}{c}\text { No. of } \\
\text { embryos/explant }\end{array}$ \\
\hline Charentais Savor- $\mathrm{R}^{\mathrm{z}}$ & 43 & $100 a^{y}$ & $20.2 \mathrm{a}^{\mathrm{x}}$ \\
\hline Eden Gem-R x I & 37 & $97.3 \mathrm{a}$ & $14.1 \mathrm{~b}$ \\
\hline Male Sterile A147-R & 56 & $76.8 \mathrm{~b}$ & $7.8 \mathrm{~cd}$ \\
\hline Hearts of Gold-R & 38 & $76.3 \mathrm{~b}$ & $6.3 \mathrm{cde}$ \\
\hline Four-fifty-R & 56 & $67.9 \mathrm{c}$ & $3.8 \mathrm{efg}$ \\
\hline Charentais Flyer-R & 51 & $64.7 \mathrm{~d}$ & $8.4 \mathrm{c}$ \\
\hline Edisto-R & 48 & $62.5 \mathrm{e}$ & $3.0 \mathrm{efg}$ \\
\hline Crenshaw-I & 55 & $61.8 \mathrm{e}$ & $6.0 \mathrm{cde}$ \\
\hline Early Green Flesh-R x I & 41 & $58.5 \mathrm{f}$ & $4.7 \mathrm{defg}$ \\
\hline Honeyshaw-I & 12 & $58.3 \mathrm{f}$ & $2.3 \mathrm{efg}$ \\
\hline Delicious 51-R & 28 & $57.1 \mathrm{f}$ & $2.6 \mathrm{efg}$ \\
\hline Grande Gold-R & 56 & $51.8 \mathrm{~g}$ & $2.5 \mathrm{efg}$ \\
\hline Ambrosia-R & 56 & $46.4 \mathrm{~h}$ & $5.4 \mathrm{cdef}$ \\
\hline Amber-I & 46 & $45.7 \mathrm{~h}$ & $2.3 \mathrm{efg}$ \\
\hline Cruger & 56 & $42.9 \mathrm{i}$ & $3.5 \mathrm{efg}$ \\
\hline Tenkei & 60 & $47.7 \mathrm{i}$ & $1.8 \mathrm{fg}$ \\
\hline Scoop-R & 54 & $40.7 \mathrm{i}$ & 2.7 efg \\
\hline Golden Beauty & 54 & $40.7 \mathrm{i}$ & $1.4 \mathrm{fg}$ \\
\hline Pulsar-R & 50 & $38.0 \mathrm{j}$ & $1.8 \mathrm{fg}$ \\
\hline Sweet N' Early-R & 56 & $37.5 \mathrm{j}$ & $2.9 \mathrm{efg}$ \\
\hline Tam Honeydew-I & 44 & $36.4 \mathrm{j}$ & $2.4 \mathrm{efg}$ \\
\hline Roadside- $R$ & 36 & $36.1 \mathrm{j}$ & $2.6 \mathrm{efg}$ \\
\hline Mainstream-R & 60 & $33.3 \mathrm{k}$ & $2.7 \mathrm{efg}$ \\
\hline Imperial 45-R & 54 & $33.3 \mathrm{kl}$ & $1.5 \mathrm{fg}$ \\
\hline Otero-R & 50 & 32.01 & $2.0 \mathrm{fg}$ \\
\hline Super Market-R & 57 & 31.61 & $1.5 \mathrm{fg}$ \\
\hline Earlisweet-R & 60 & $30.0 \mathrm{~m}$ & $1.7 \mathrm{fg}$ \\
\hline Luscious- $\mathrm{R}$ & 40 & $27.5 n$ & $1.7 \mathrm{fg}$ \\
\hline Dixie Jumbo-R & 44 & $27.3 \mathrm{n}$ & $1.3 \mathrm{fg}$ \\
\hline Alaska & 26 & $26.9 n$ & $0.6 \mathrm{~g}$ \\
\hline Schoons Hardshell-R & 56 & $26.8 n$ & $1.3 \mathrm{fg}$ \\
\hline Classic-R & 56 & $26.8 \mathrm{n}$ & $1.5 \mathrm{fg}$ \\
\hline Sweet Granite-R & 54 & 25.9 no & $1.3 \mathrm{fg}$ \\
\hline Iroquois- $\mathbf{R}$ & 48 & $25.0 \mathrm{op}$ & $1.4 \mathrm{fg}$ \\
\hline Planters Jumbo-R & 20 & $25.0 \mathrm{op}$ & $1.6 \mathrm{fg}$ \\
\hline Honeydew Green Meated- & A-I 20 & $25.0 \mathrm{op}$ & $1.3 \mathrm{fg}$ \\
\hline Saticoy-R & 53 & $24.5 \mathrm{p}$ & $0.7 \mathrm{~g}$ \\
\hline Honey Rock-R x I & 29 & 24.1 & $0.3 \mathrm{~g}$ \\
\hline Tesoro-R & 58 & $24.1 \mathrm{pq}$ & $1.2 \mathrm{fg}$ \\
\hline Golden Honeymoon-I & 54 & $24.1 \mathrm{pq}$ & $1.8 \mathrm{fg}$ \\
\hline Fruit Punch & 46 & $23.9 \mathrm{pq}$ & $0.8 \mathrm{~g}$ \\
\hline P.M. Resistant 45-R & 56 & $23.2 \mathrm{q}$ & $1.0 \mathrm{fg}$ \\
\hline Tasty Sweet-R & 51 & $21.6 \mathrm{r}$ & $0.4 \mathrm{~g}$ \\
\hline Hastings Honeydew-I & 14 & $21.4 \mathrm{r}$ & $2.0 \mathrm{fg}$ \\
\hline Rocky Sweet-R x I & 43 & $18.6 \mathrm{~s}$ & $1.1 \mathrm{fg}$ \\
\hline Aurora- $\mathrm{R}$ & 19 & $15.8 \mathrm{t}$ & $1.9 \mathrm{fg}$ \\
\hline Jung Earlidew-I & 60 & $13.3 \mathrm{u}$ & $0.5 \mathrm{~g}$ \\
\hline Orange Flesh-I & 55 & $12.7 \mathrm{u}$ & $0.5 \mathrm{~g}$ \\
\hline Earligold-R & 22 & $9.0 \mathrm{v}$ & $0.2 \mathrm{~g}$ \\
\hline Mellingers CA-12-I & 40 & $7.5 \mathrm{w}$ & $0.1 \mathrm{~g}$ \\
\hline Topmark-R & 47 & $6.4 \mathrm{x}$ & $0.3 \mathrm{~g}$ \\
\hline Hastings Earlidew-I & 60 & $5.0 \mathrm{y}$ & $0.1 \mathrm{~g}$ \\
\hline
\end{tabular}

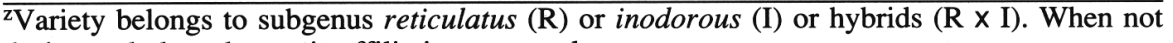
designated, the subgeneric affiliation was unclear.

${ }^{\mathrm{y}}$ Mean separation in columns by analysis of standard errors from categorical modeling, $P=0.05$.

${ }^{x}$ Mean separation in columns by Student-Newman-Keul's test, $P=0.01$. 
in ED media were significantly better than all other treatments, except that with $3.0 \%$ sucrose in EI medium and $6.0 \%$ sucrose in ED medium.

Sucrose concentration also exerted an effect on the relative percentage of somatic embryo stages recovered and on abnormal embryo development and precocious germination (Table 6). There were no differences among treatments with respect to recovery of globular embryos (data not shown). More torpedo stage embryos were obtained with the $3.0 \%$ to $1.5 \%$ treatment than from treatments with either $1.5 \%$ or $6.0 \%$ sucrose in EI medium; the responses from $3.0 \%$ to $3.0 \%$ and $3.0 \%$ to $6.0 \%$ treatments were statistically intermediate. A similar trend occurred in the percentage of cotyledonary stage embryos, where the $3.0 \%$ to $6.0 \%$ treatment was similar to the other treatment with $3.0 \%$ sucrose in EI but better than the others. Treatments that produced the highest percentage of responding explants also resulted, generally, in more abnormal embryo development and more precocious germination. For example, the treatment with $3.0 \%$ sucrose in both media (EI and ED) produced $100 \%$ and $99 \%$ abnormal and precociously germinating explants, respectively. Sucrose appears to affect not only the magnitude of embryogenic response but also abnormal development and precocious germination.

Response of C. melo varieties to improved culture protocol. The improved protocol for high-frequency somatic embryogenesis that emerged from preceding optimization experiments uses basal halves of cotyledons from quiescent seed for explants and involves an embryo induction step on MS medium containing 3\% sucrose, 2,4-D at $5 \mathrm{mg} \cdot$ liter $^{-1}$ and TDZ at $0.075 \mathrm{mg} \cdot \mathrm{liter}^{-1}$ in

\section{Literature Cited}

Chee, P.P. 1991. Plant regeneration from cotyledons of Cucumis melo 'Topmark'. HortScience 26:908-910.

Compton, M.E. and D.J. Gray. 1991. Somatic embryogenesis and plant regeneration from immature cotyledons of watermelon. HortScience 26: 110. (Abstr.)

Compton, M.E. and D.J. Gray. 1993. Somatic embryogenesis and plant regeneration from immature cotyledons of watermelon. Plant Cell Rpt. 12:61-65.

Compton, M.E. and D.J. Gray. 1993. Shoot organogenesis and plant regeneration from cotyledons of diploid, triploid, and tetraploid watermelon. J. Amer. Soc. Hort. Sci. 118:151-157.

Dirks, R. and M. van Buggenum. 1989. In vitro plant regeneration from leaf and cotyledon explants of Cucumis melo L. Plant Cell Rpt. 7:626627.

Gray, D.J. and C.M. Benton. 1991. In vitro micropropagation and plant establishment of muscadine grape cultivars (Vitis rotundifolia). Plant Cell Tissue \& Organ Cult. 27:7-14.

Gray, D.J., D.W. McColley, and M.E. Compton. 1992. Effects of cytokinins, genotype and other factors on somatic embryogenesis from cotyledons of Cucumis melo. In Vitro Cell. Dev. Biol. 28:100.(Abstr.)

Homma, Y., K. Sugiyama, and K. Oosawa. 1991. Improvement in production and regeneration of somatic embryos from mature seed of melon (Cucumis melo L.) on solid medium. Jpn. J. Breeding 41:543-551.

Kageyama, K., K. Yabe, and S. Miyajima. 1990. Somatic embryogenesis and plant regeneration from stem, leaf, and shoot apex of melon (Cucumis melo L.). Plant Tissue Cult. Lett. 7:193-198.

Kageyama, K., K. Yabe, and S. Miyajima. 1991. Somatic embryogenesis in suspension culture of mature seed of Cucumis melo L. Jpn. J. Breeding 41:273-278.

Malik, K.A. and P.K. Saxena. 1992. Regeneration in Phaseolus vulgaris L.: High-frequency induction of direct shoot formation in intact seedlings by N6-benzylaminopurine and thidiazuron. Planta 186:384-389.

Moreno, V., M. Garcia-Sogo, I. Granell, and B. Garcia-Sogo. 1985. Plant darkness for 2 weeks, followed by an embryo development step on MS medium with 3\% sucrose in light. Embryos begin to form within the first 2 weeks, and maximum number of embryos occur within 7 weeks from culture initiation.

The improved culture protocol was tested on 51 commercially available varieties and one breeding line ('Male Sterile A147'). We found a wide range in response among the varieties (Table 7). For 'Charentais Savor' and 'Eden Gem', 100\% and 97.7\% of explants responed, respectively, with 20 and 14 embryos per explant. These are the highest responses reported for $C$. melo to date. The seven best responding varieties were all members of subgenus reticulatus (except for 'Eden Gem', which was a reticulatus $\times$ inodorus hybrid), although somatic embryogenesis was also obtained within subgenus inodorus. Oridate et al. (1992) also listed reticulatus varieties as being more embryogenic than inodorus varieties. Comparison of two commercial sources of 'Earlidew' demonstrated a significant difference in the frequency of embryogenic explants. This result illustrates variation among seed lots that can lead to difficulties in repeatability of experiments. Embryos from each variety were placed on GM medium to test their ability to germinate into plants. Plants of normal appearance have been obtained from $>60 \%$ of the varieties. Although obtaining plants from this culture system has not been an obstacle, further optimization of embryo germination and plant recovery is possible.

The fact that all 52 varieties tested underwent somatic embryogenesis suggests that $C$. melo may be particularly amenable to various biotechnical procedures that require a cell regeneration system.

regeneration from calli of melon (Cucumis melo L., cv. 'Amarillo Oro'). Plant Cell Tissue \& Organ Cult. 5:139-146.

Murashige, T. and F.M. Skoog. 1962. A revised medium for rapid growth and bioassays with tobacco tissue cultures. Physiol. Plant. 15:473-497.

Nejidat, A., W.M. Clark, and R.N. Beachy. 1990. Engineered resistance against plant disease. Physiol. Plant. 80:662-668.

Niedz, R.P., S.S. Smith, K.B. Dunbar, C.T. Stephens, and H.H. Murakishi. 1989. Factors influencing shoot regeneration from cotyledonary explants of Cucumis melo. Plant Cell Tissue \& Organ Cult. 18:313-319. Nugent, G., T. Wardley-Richardson, and C.Y. Lu. 1991. Plant regeneration from stem and petal of carnation (Dianthus caryophyllus L.). Plant Cell Rpt. 10:477-480.

Oridate, T., H. Atsumi, S. Ito, and H. Araki. 1992. Genetic differences in somatic embryogenesis from seeds in melon (Cucumis melo L.). Plant Cell Tissue \& Organ Cult. 29:27-30.

Oridate, T. and K. Oosawa. 1986. Somatic embryogenesis and plant regeneration from suspension callus culture in melon (Cucumis melo L.). Jpn. J. Breeding 36:424-428.

Punja, Z.K., N. Abbas, G.G. Sarmento, and F.A. Tang. 1990. Regeneration of Cucumis sativus var. sativus and C. sativus var. hardwickii, $C$. melo, and C. metuliferus from explants through somatic embryogenesis and organogenesis. Plant Cell Tissue \& Organ Cult. 21:93-102.

SAS Institute. 1988. SAS user's guide: Statistics. version 6.03. SAS Inst., Cary, N.C.

Shimonishi, K., M. Ishikawa, S. Suzuki, and K. Oosawa. 1991. Cryopreservation of melon somatic embryos by desiccation method. Jpn. J. Breeding 41:347-351.

Tabei, Y., T. Kanno, and T. Nishio. 1991. Regulation of organogenesis and somatic embryogenesis by auxin in melon, Cucumis melo L. Plant Cell Rpt. 10:225-229.

Trulson, A.J. and E.A. Shahin. 1986. In vitro plant regeneration in the genus Cucumis. Plant Sci. 47:35-43.

van der Wolk, J.M.A.S.A., D.J. Gray, and G.W. Elmstrom. 1986. Somatic embryogenesis and plant regeneration from field-grown apices of male sterile cantaloupe. 22nd. Int. Hort. Congr., HortScience 21:761. (Abstr.) 